\title{
1 Preliminary analysis of a neotropical plant extract antiviral potential 2 against Chikungunya and Mayaro viruses
}

4 Ellen Caroline Feitoza Pires ${ }^{1}$; Francini Pereira da Silva ${ }^{2}$; Karoline Schallenberger ${ }^{2}$; Bruna Saraiva

$5 \quad$ Hermann$^{2}$; Larissa Mallmann ${ }^{2}$; Alini Godinho dos Santos ${ }^{1}$; Wellington S. Moura ${ }^{1}$; Eugênio E. de

6 Oliveira ${ }^{4}$; Guy Smagghe ${ }^{5}$; Sergio Donizeti Ascêncio ${ }^{3}$; Robson dos Santos Barbosa ${ }^{3}$; Ilsamar

$7 \quad$ Mendes $^{3}$; Juliane Deise Fleck ${ }^{2}$; Bergmann Morais Ribeiro6,"; Raimundo Wagner de Souza

8 Aguiar $^{1}$

$10{ }^{1}$ Department of Biotechnology, Molecular Biology Laboratory, Federal University of Tocantins, 11 Gurupi, Tocantins, Brazil.

${ }^{2}$ Institute of Health Sciences, Molecular Microbiology Laboratory, Feevale University, Novo Hamburgo, Rio Grande do Sul, Brazil.

${ }^{3}$ Department of Biotechnology Biodiversity and Graduate School of Biotechnology of Amazônia (Bionorte), Natural Products Laboratory, Federal University of Tocantins, Palmas, Tocantins, Brazil.

${ }^{4}$ Department of Entomology, Federal University of Viçosa, Viçosa, Minas Gerais, Brazil.

${ }^{5}$ Department of Plants and Crops, Faculty of Bioscience Engineering, Ghent University, Ghent, Belgium.

${ }^{6}$ Department of Cell Biology, Institute of Biology, University of Brasília, Brasília, Distrito Federal, Brazil.

27

28

$29 *$ Corresponding author:

30 E-mail: bergmann@unb.br 


\section{Abstract}

33 Chikungunya and Mayaro fevers are viral infectious diseases, without vaccine or

34 treatment, that causes fever and arthralgia. Establishing novel antiviral tools capable of preventing or treating Chikungunya virus (CHIKV), and Mayaro virus (MAYV) infections are needed. The use of plant-based compounds that affect the replication cycles

37 of these viruses has been proposed as a promising strategy. Chiococca alba (L.) Hitchc.

38 is a neotropical plant used by Yucatec Mayas traditional healers, mainly, as antipyretic

39 and antirheumatic. To evaluate the potential of $C$. alba methanolic extracts against

40 CHIKV and MAYV through preliminary analysis in vitro and in silico. The cytotoxicity

41 profile of two C. alba roots methanolic extracts in Vero cells was performed by lysosomal

42 viability using the neutral red assay, and the antiviral potential was determined by plaque

43 assay. We further assessed, through in silico computational predictions, the possible

44 interactions between the active site of the nsP2 proteases of these viruses with some secondary metabolites present in C. alba extracts, identified by High-Performance Liquid

Chromatography (HPLC). Our partial phytochemical analysis revealed the presence of

47 flavonoids, and phenolic acids in the C. alba extracts. Our in vitro assays showed that both $C$. alba extracts inhibited more than $70 \%$ of CHIKV and MAYV activities at 60 $\mu \mathrm{g} / \mathrm{mL}$ concentration. Based on our in silico computational predictions, the flavonoids naringin and vitexin showed the greatest affinity energies with the CHIKV and MAYV $\mathrm{nsP} 2$ proteases, revealing the great potential of these compounds as viral inhibitors. The

52 findings described here indicates that $C$. alba extracts, or their secondary metabolites, as

53 a potential source of novel antiviral compounds.

54 Keywords: Chiococca alba; flavonoids; Alphavirus; potential antiviral; nsP2 protease; 55 molecular docking 


\section{$57 \quad$ Introduction}

Arboviruses diseases have a high impact on public health in many countries of the

neotropical regions, due to frequent disease outbreaks and epidemics [1]. Chikungunya virus (CHIKV) and Mayaro virus (MAYV) are arboviruses transmitted through female mosquito bite of the genus Aedes [2]. They belong to the Togaviridae family and the Alphavirus genus, and clinically, the disease caused by CHIKV and MAYV is similar to dengue, characterized by fever, headache, and arthralgia $[3,4]$.

Their genomes have two Opening Reading Frames (ORF's), the first encodes four nonstructural proteins (nsP1, nsP2, nsP3, and nsP4), and the second encodes proteins related to the structure of the viral particle: capsid (C), envelope glycoproteins (E1 and E2) and two cleavage products (E3 and 6k) [6,7]. Alphavirus non-structural proteins are involved in viral replication and transcription and, therefore, are potential targets for the development of inhibitors, mainly nsP2 due to their multi-action in viral replication [8, 9].

Plant-derived substances have been widely studied as sources of compounds with antiviral activity [10]. Among these, we can mention the products of secondary metabolism of different plant species [11], which have shown antiviral potential against several viruses [12]. Examples of these metabolites are alkaloids, saponins, flavonoids, and coumarins [13]. However, besides having high antiviral activity, metabolites also

77 need to have low cytotoxicity to cells. Among the metabolites with antiviral activity mentioned in the literature, flavonoids stand out [14].

Rubiaceae family plant species are known to produce secondary metabolites with pharmacological activities, mainly, flavonoids, alkaloids and saponins $[15,16,17]$. The 
81 species Chiococca alba (L.) Hitchc. (Rubiaceae) is a 2 to 3 meters high shrub endemic to

82 the American continent, commonly known in Brazil as "Cainca" [18, 19]. The C. alba

83 was used for medicinal purposed by the Yucatec Mayas traditional healers of Southern

84 Belize, in Central America, to treat fever, cold, and muscle pains [20, 21]. Roots' infusion

85 is used in traditional medicine as antirheumatic, antiasthmatic, diuretic, anti-

86 inflammatory, and antimicrobial activity $[22,23]$.

87 Considering the symptoms of intermittent fever caused by infection with CHIKV 88 and MAYV, associated with the Mayas Yucatec ethnobotanical knowledge, this study

89 aimed to evaluate the effectiveness of methanolic plant extracts from the C. alba roots, 90 as a potential antiviral agent against CHIKV and MAYV in Vero cell lineage in vitro. We

91 also analyzed the in silico interaction of two identified compounds in the plant extract

92 with the CHIKV and MAYV nsP2 protease. 


\section{$94 \quad$ Materials and methods}

\section{Plant material}

C. alba roots were collected in Formoso do Araguaia (1 $1^{\circ} 47^{\prime} 48^{\prime \prime}$ latitude $\mathrm{S}, 49^{\circ}$

97 31'44" longitude O), Tocantins state, Brazil [24]. The plant was identified at the

98 herbarium of the Department of Environmental Studies of the Federal University of

99 Tocantins (Campus Porto Nacional), where the specimen voucher was deposited under

100 the code (HTO-11.160). The research was authorized by the Sistema Nacional de Gestão 101 do Patrimônio Genético e do Conhecimento Tradicional Associado - SISGEN, $\mathrm{n}^{\circ}$ 102 A77A809.

103

\section{Preparation of extracts}

The plant material powder was subjected to two different extraction processes: by maceration (CAH21) and to the Soxhlet extractor (Marconi, model MA-487/6/25, Brazil)

107 (CAH24). For the CAH21 process, powder roots (500g) were extracted at room temperature $\left(25^{\circ} \mathrm{C}\right)$ for three days with methanol $(\mathrm{MeOH})$, and for the $\mathrm{CAH} 24$ process, powder roots $(500 \mathrm{~g})$ were extracted at $60{ }^{\circ} \mathrm{C}$ for $4 \mathrm{~h}$ with $\mathrm{MeOH}$. The samples were

110 filtered through Whatman No. 1 filter paper (GE Healthcare Life Sciences, USA), and the

111 liquid fractions were concentrated with rotary evaporator to obtain the crude extracts [25,

112 26]. Each methanol extract was lyophilized and stored in a moisture-free desiccator until

113 use. The stock solutions were prepared $(10.000 \mu \mathrm{g} / \mathrm{mL})$, and no organic solvents were

114 used to solubilize the extracts, only DMEM medium. Before the assays, the fractions were 115 filtered in Durapore ${ }^{\circledR}$ membrane filter, $0.22 \mu \mathrm{m}$. 


\section{Chemical analysis of extracts}

119 High-Performance Liquid Chromatography (HPLC) at the Natural Products Laboratory

120 of the Federal University of Tocantins using a SHIMADZU ${ }^{\circledR}$ HPLC system (Kyoto, 121 Japan) consisting of a LC-10ATVp pump, CTO-10A column oven, DGU14A degasser, 122 SCL 10A system controller, Shimadzu SPD-10AT UV-VIS detector and a loop injector 123 with a loop size of $20 \mu \mathrm{L}$.

124 The chromatographic analysis was carried out in gradient conditions using a C-18 125 reverse phase column $(250 \times 4.6 \mathrm{~mm}$, particle size $5 \mu \mathrm{m}$, Luna $5 \mu \mathrm{C}$-18). The elution 126 solvent consisted of $0,1 \%$ phosphoric acid in water (Solvent A) and $0.1 \%$ phosphoric acid 127 in water/acetonitrile/ methanol (54:35:11 v/v) (solvent B). The elution gradient was used 128 as follow: 0-5 $\min , 0 \% \mathrm{~B}$; 5-10 $\mathrm{min}, 30 \% \mathrm{~B}, 10-20 \mathrm{~min}, 40 \% \mathrm{~B}, 20-60 \min 40 \% \mathrm{~B}, 60-$ $12970 \min 50 \%$ B, $70-90 \min 60 \%$ B, $90-100 \min 80 \%$ B, $100-110 \min 100 \%$ B. $110-120$ $130 \mathrm{~min} 100 \% \mathrm{~B}$. The flow rate was $1.0 \mathrm{~mL} / \mathrm{min}$ and the detection wavelength was $280 \mathrm{~nm}$. 131 Compounds were identified by comparing sample retention times with 16 available 132 authentic standards (Figure S1) (Sigma - Aldrich, EUA). The concentrations of the 133 identified compounds have not been determined.

\section{Cells and viruses}

Vero Cells (ATCC ${ }^{\circledR}$ : CCL81) - from African green monkey kidney

137 (Cercopithecus aethiops), available from the Feevale University Molecular Microbiology 138 (LMM) stock (Rio Grande do Sul, Brazil), were cultured in Dulbecco's modified Eagle 
139 medium (DMEM) (Cultilab, Brazil) supplemented with 10\% fetal bovine serum (FBS)

140 (Cultilab). Cells were maintained at $37^{\circ} \mathrm{C}$ in $5 \% \mathrm{CO}_{2}$ [27].

141 Viral isolates used in the experiments were CHIKV \# 3 isolate from a Brazilian

142 clinical sample and MAYV BeAr 20290 (GenBank accession no. KT754168). Vero cells

143 were infected with a Multiplicity of Infection $(\mathrm{MOI})=0,01$, in a $75 \mathrm{~cm}^{2}$ culture flask

144 containing a monolayer of $8.5 \times 10^{6}$ cells. The infected cells were incubated for $48 \mathrm{~h}$ at 37

$145{ }^{\circ} \mathrm{C}$ in $5 \% \mathrm{CO}_{2}$. The supernatant of the cells was collected and kept at $-80^{\circ} \mathrm{C}$ until viral 146 titration [28].

\section{Viral titration by plaque assay}

Titration was performed for each virus, whose experiments were previously standardized in the LMM [29]. The semi-solid medium was prepared with 2X Minimum

151 Essential Medium (MEM) (Cultilab, Brazil), and carboxymethylcellulose (CMC) 1.5\% and $1 \%$ for titration of CHIKV and MAYV, respectively.

For cell fixation, $4 \%$ formaldehyde was added for $30 \mathrm{~min}$, followed by $1 \mathrm{X}$ phosphate-buffered saline (PBS, 137.0 $\mathrm{mM} \mathrm{NaCl}, 2.7 \mathrm{mM} \mathrm{KCl}, 10.0 \mathrm{mM} \mathrm{Na}_{2} \mathrm{HPO}_{4}, 2.0$ $\mathrm{mM} \mathrm{KH} \mathrm{KO}_{4}, \mathrm{pH}$ 7.4) [30], and 0,2\% violet crystal (Synth, BRA) remaining under stirring for $30 \mathrm{~min}$. Then, the violet crystal was removed, and the plates were dried at

157 room temperature. After drying, the formed lysis plaques were counted, and the viral titer 158 was calculated, whose values were expressed in plaque-forming units (PFU/mL). 


\section{Cytotoxicity assay}

162 lysosomal viability, using the standardized neutral red incorporation assay at the Feevale

163 University Cytotoxicity Laboratory [31]. For this, 96 well microplates were prepared 24

$164 \mathrm{~h}$ in advance, using Vero cells at a concentration of $2 \times 10^{5}$ cells/well. After the medium was removed, and $150 \mu \mathrm{L}$ of the serial dilutions of each extract (starting from $1 \mathrm{mg} / \mathrm{mL}$ ) was added in triplicate. Untreated cells were used as controls, adding an equal volume $167(150 \mu \mathrm{L})$ of DMEM medium supplemented. The plate remained in an incubator at $37^{\circ} \mathrm{C}$ 168 in $5 \% \mathrm{CO}_{2}$ for $48 \mathrm{~h}$. concentration with those obtained for the respective cellular controls (classified as 100\% viable). Extract concentration that is toxic to $50 \%$ of the cells $\left(\mathrm{CC}_{50}\right)$ was calculated using the dose-response curve, and the experiment was carried out in triplicate with three

173 independent replications.

\section{Antiviral assays}

For the antiviral activity tests, microplates were prepared as previously described.

177 After incubation at $37^{\circ} \mathrm{C}$ in a humidified environment of $5 \% \mathrm{CO}_{2}$, the viral suspension

178 (100 PFU/mL) was inoculated, adding only DMEM in the wells corresponding to cell

179 control and cytotoxicity control. After $1 \mathrm{~h}$ of incubation, with slow shaking, every 15 min,

180 the respective viral suspensions and the medium (cell control and cytotoxicity control 181 wells) were aspirated, and then the semi-solid medium was added. Different concentrations of plant extracts $(40,60,80$, and $100 \mu \mathrm{g} / \mathrm{mL})$ were added and designated 
183 treatment wells. The highest concentration of the extract was used $(100 \mu \mathrm{g} / \mathrm{mL})$ for the 184 cytotoxicity control. The microplates were incubated at $37{ }^{\circ} \mathrm{C}$ under a $\mathrm{CO}_{2}$ atmosphere 185 of $5 \%$ for $48 \mathrm{~h}$. Thus, they were fixed and stained as previously described. The analysis 186 was carried out in duplicate, and at least three independent experiments were performed, 187 followed by the standardized protocol for each virus. $100-[(B \times 100) / C]$, where $A$ is the $\%$ in the number of plaques reduced, $B$ is the average number of plaques for treatments and $C$ is the viral control number of plaques [32]. Halfmaximal inhibitory concentration $\left(\mathrm{IC}_{50}\right)$ with the respective $95 \%$ confidence intervals $\mathrm{CC}_{50} / \mathrm{IC}_{50}$

In silico analysis of the interaction between molecules of $C$. alba nsP2 protease from the CHIKV [Protein Data Base (PDB) model ID: 4ZTB] as a model.

201 For the CHIKV nsP2 protease structure, the file was obtained directly from the PDB (ID: 202 3TRK).

C. alba molecules - naringin, syringic and chlorogenic acids, vitexin, myricetin,

204 and quercetin, were modeled using Marvin Sketch 18.10 (ChemAxon). Receptors and 205 ligands molecular docking were performed using Autodock Tools 1.5.7 [33], according 
206 to the methodology proposed by our colleagues [34]. Docking calculations were

207 performed using AutoDock Vina. Nine docking positions were generated for each ligand,

208 through the interaction with the target proteins returning affinity energy values

209 (Kcal/mol) [35]. Docking position results were analyzed using PyMOL 2.0 [36] and

210 Discovery Studio 4.5 [37] to select the best location for each ligand within the protein

211 target [34].

212

\section{Statistical analysis}

214 For all tests, the GraphPad Prism ${ }^{\circledR}$ software (GraphPad Software, San Diego, CA,

215 USA) version 6.0 was used. For cell viability, the results obtained were submitted to the

216 Shapiro-Wilk normality test. For all analyzes, $\mathrm{p}<0.05$ were considered statistically

217 significant.

218 


\section{Results}

\section{Chemical profiles of $C$. alba $\mathrm{CAH} 21$ and CAH24 extracts}

222 the CAH21 extract (S2 Fig.), and 21 peaks in the CAH24 extract (S3 Fig.). From the 223 standards used (S1 Fig.), CAH21 extract revealed the presence of a flavonoid - naringin, 224 and CAH24 extract showed the acids: syringic and chlorogenic, and flavonoids: vitexin, 225 myricetin, and quercetin (Table 1).

227 Table 1. Chemical profile of $C$. alba extracts identified by HPLC.

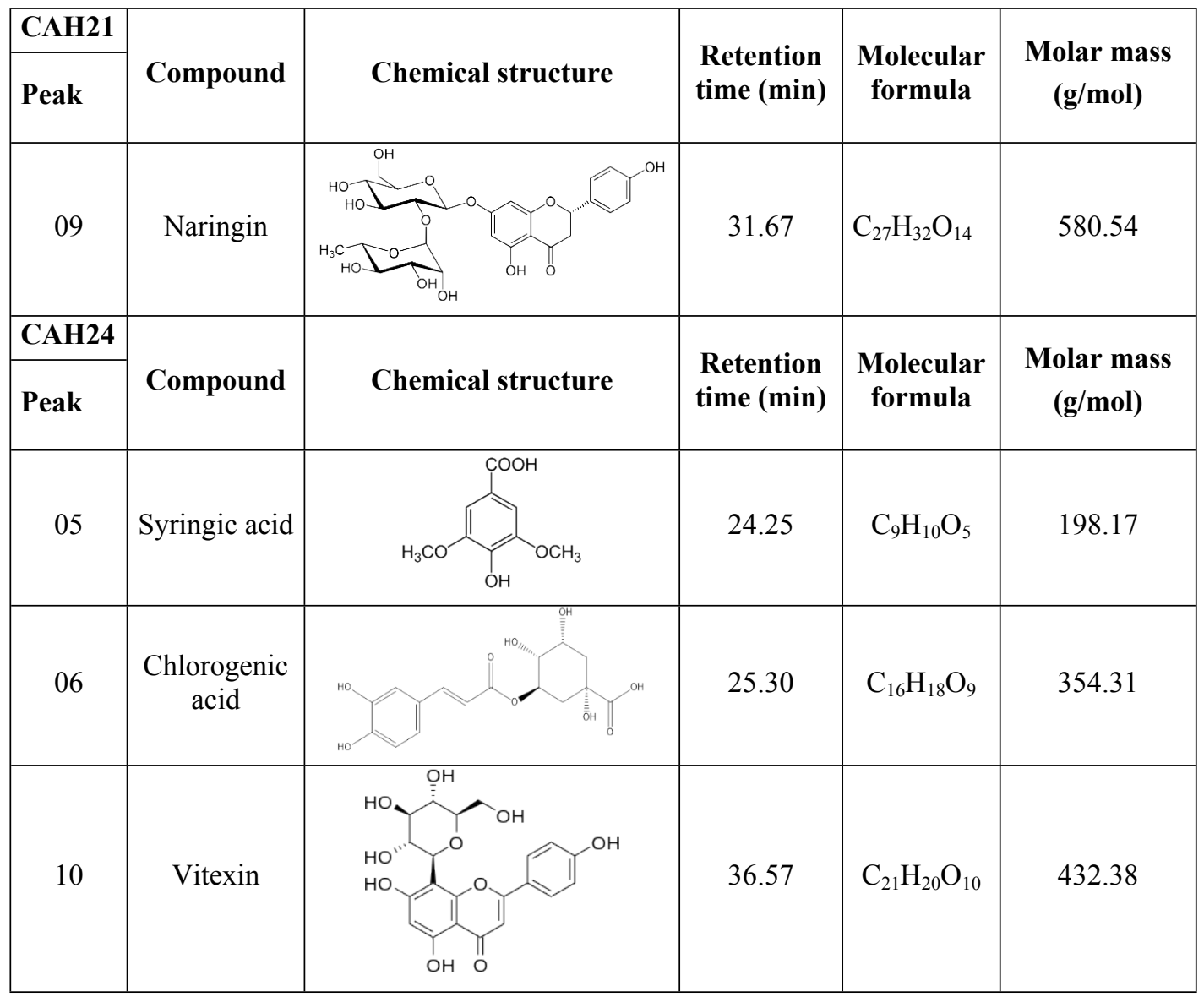




\begin{tabular}{|l|l|l|l|l|l|}
\hline 12 & Myricetin & Quercetin & &
\end{tabular}

CAH21 and CAH24 C. alba extracts were incubated with Vero cells for $48 \mathrm{~h}$, and

232 the $\mathrm{CC}_{50}$ was calculated by nonlinear regression (curve fit). They showed close toxicities to Vero cells in $48 \mathrm{~h}$, and the $\mathrm{CC}_{50}$ values were $90 \pm 1.4 \mu \mathrm{g} / \mathrm{mL}$ and $100 \pm 1.3 \mu \mathrm{g} / \mathrm{mL}$, respectively (Fig 1 and Table 2). The cytotoxic effects observed were the formation of vacuoles and cell lysis.

Fig 1. Cytotoxicity assay. Cell viability after treatment using Vero cells, incubated for $48 \mathrm{~h}$, with different concentrations of $C$. alba extracts (A) CAH21 and (B) CAH24.

Table 2. Cytotoxic concentration $\left(\mathrm{CC}_{50}\right)$, selectivity index (SI), and reduction percentage in the plaques number for $C$. alba extracts against CHIKV and MAYV in Vero cells after $48 \mathrm{~h}$.

\begin{tabular}{|c|c|c|c|c|c|c|}
\hline \multirow{2}{*}{$\begin{array}{c}\text { Plant } \\
\text { extracts }\end{array}$} & $\begin{array}{c}\mathbf{C C}_{\mathbf{5 0}} \\
(\boldsymbol{\mu g} / \mathbf{m L})^{\mathbf{a}}\end{array}$ & $\begin{array}{c}\text { Concentration } \\
(\boldsymbol{\mu g} / \mathbf{m L})\end{array}$ & $\begin{array}{c}\text { CHIKV \% } \\
\text { reduction }\end{array}$ & $\begin{array}{c}\text { Selectivity } \\
\text { Index }^{\mathbf{d}}\end{array}$ & $\begin{array}{c}\text { MAYV \% } \\
\text { reduction }^{\mathbf{c}}\end{array}$ & $\begin{array}{c}\text { Selectivity } \\
\text { Index }^{\mathbf{e}}\end{array}$ \\
\hline \multirow{2}{*}{ CAH21 } & $89.66 \pm 1.37$ & 40 & $47.59 \pm 4.62$ & & $61.62 \pm 4.59$ & \multirow{2}{*}{1.48} \\
\cline { 3 - 6 } & & 60 & $73.61 \pm 7.98$ & & $79.94 \pm 4.39$ & \\
\hline
\end{tabular}




\begin{tabular}{|c|c|c|c|c|c|c|}
\hline & & 80 & $88.03 \pm 5.91$ & & $98.14 \pm 4.85$ & \\
\hline & & 100 & $92.63 \pm 3.39$ & & $100 \pm 6.40$ & \\
\hline \multirow{4}{*}{ CAH24 } & \multirow{4}{*}{$100.5 \pm 1.26$} & 40 & $60.84 \pm 7.49$ & \multirow{4}{*}{1.76} & $74.35 \pm 1.89$ & \multirow{4}{*}{1.53} \\
\hline & & 60 & $79.77 \pm 10.13$ & & $83.46 \pm 4.69$ & \\
\hline & & 80 & $92.33 \pm 3.63$ & & $95.79 \pm 1.93$ & \\
\hline & & 100 & $95.81 \pm 0.76$ & & $100 \pm 0.00$ & \\
\hline
\end{tabular}

$244 \mathrm{~b}, \mathrm{c} T$ The reported values are mean $\pm \mathrm{SD}$ of the triplicate assay for each sample.

$245 \quad \mathrm{~d},{ }^{\mathrm{e}} \mathrm{CC}_{50} / \mathrm{IC}_{50}$.

\section{Antiviral activity analysis}

248 Comparing the two extracts, CAH21 showed a less toxic profile for both viruses

249 tested (S4 and S5 Figs.). CHIKV plaque formation reduction, when using the C. alba

250 extracts CAH21 and CAH24, was higher than $70 \%$ at $60 \mu \mathrm{g} / \mathrm{mL}$. At $40 \mu \mathrm{g} / \mathrm{mL}, \mathrm{CAH} 21$

251 showed $48 \%$ plaque formation reduction (Fig 2 A).

252

253 Fig 2. Antiviral assay. Evaluation of the antiviral activity of $C$. alba extracts (CAH21

254 and $\mathrm{CAH} 24$ ) by reduction percentage in the plaques number of CHIKV (A) and MAYV

255 (B). IC50 = Inhibitory concentration $50 \%$ of cells; $95 \%$ CI = Confidence intervals of $95 \%$. 
Table 3. Molecular docking results for the complexes formed between the $C$. alba extracts molecules and the nsP2 proteins of CHIKV and MAYV.

\begin{tabular}{|c|c|c|}
\hline \multirow{2}{*}{ Molecules } & \multicolumn{2}{|c|}{ Receptor $(\mathrm{kcal} / \mathrm{mol})^{\mathrm{a}}$} \\
\hline & nsP2 protease - CHIKV & nsP2 protease - MAYY \\
\hline Chlorogenic acid & -6.7 & -6.8 \\
\hline Myricetin & -7.0 & -7.1 \\
\hline Naringin & -7.9 & -8.5 \\
\hline Quercetin & -7.1 & -7.3 \\
\hline Syringic acid & -4.6 & -4.9 \\
\hline Vitexin & -7.9 & -7.9 \\
\hline
\end{tabular}

\section{Modeling and validation of the MAYV nsP2 structure}

The MAYV's nsP2 three-dimensional structure was modeled (Fig 4 B) using the

CHIKV's nsP2 as a model (PBD ID: 4ZTB). For the appropriate model construction, in the functionality of the model. Ideally, this identity should exceed $30 \%$ [33], and we

271 found a $67.50 \%$ identity about the model used to build the protein three-dimensional

272 structure. About the Ramachandran graph, we obtained 93.08\%, and -0.79 to QMEAN

273 analysis (Fig 3 A and B), affirming that the model is located in the most favorable region,

274 close to 0, being an appropriate model [34].

275

276 Fig 3. MAYV nsP2 structure modeling and validation. Ramachandran graph for

277 MAYV nsP2 (A). The black arrow indicates the presence of the protein in the most 278 favorable region; QMEAN (Qualitative Model Energy Analysis) value, which describes 279 the quality of the model (B). The red star indicates position in Z-scores presents a highly 
280 reliable structure and is within the range of scores typically found for proteins of similar 281 size.

\section{Molecular docking}

According to in silico analysis, the molecules identified in the C. alba extracts can interact with the CHIKV and MAYV nsP2 protein, showing different affinity energies, as described in table 3. Based on the best interaction energies between molecule-receptor, naringin and vitexin showed a strong interaction with $n s \mathrm{P} 2$, thus being potential antiCHIKV and anti-MAYV molecules. The molecular docking using naringin and vitexin with nsP2 of CHIKV and MAYV was used to assess the antiviral potential of these 290 flavonoids, based on the hypothesis that flavonoids may interfere in the viral replication 291 cycle. site. The naringin-CHIKV-nsP2 complex showed van der Waals interactions (SER44, PRO204, LEU203, ALA205, and ALA76), one pi-alkyl interaction and one pi-sigma with TYR75 amino acid, hydrogen carbon interactions (LEU201 and ASP229), and one pi-

297 cation interaction (TRP80) (Fig 4 A). The MAYV nsP2 protease was also used as a target. 298 The vitexin-MAYV-nsP2 showed van der Waals interactions (amino acids MET706, 299 GLN709, SER517, VAL520, THR736, ARG735, HIS552, LEU546, GLY559, ARG560 and ALA743), a carbon hydrogen interaction (TYR548), a pi-alkyl interaction (TRP553), and pi-cation interaction (GLU519) (Fig 4 B). The naringin-MAYV-nsP2 complex 302 showed a total of 15 interactions, with van der Waals bonds (TYR717, GLY713, 303 GLN709, VAL520, GLU519, ARG560, LEU546, GLY559, and TYR548), carbon 
304 hydrogen (ASP714, MET710, HIS552, and SER517), and pi-alkyl (TRP553 and 305 LEU716) (Fig 4 B).

307 Fig 4. Molecular docking. Complex between nsP2 protease of CHIKV (A) and MAYV

308 (B) with molecules ligand naringin (green) and vitexin (red), close to the region of the 309 active site (yellow), and 2D interaction map with the amino acids.

\section{Discussion}

In this work, we have showed that $C$. alba methanolic plant extracts have potential anti-CHIKV and anti-MAYV. The cytotoxicity of $C$. alba extracts to Vero cells was

314 determined, establishing a concentration-response curve. An antiviral drug must have 315 activity against the virus without inducing significant toxicity to the host cell, so the first step for antiviral tests is to investigate the cytotoxic activity. Given the crude nature of

317 the tested extracts, the observed cytotoxic effects can be related to the molecules present and theirs concentrations, since the stock solutions was prepared without organic solvents. The higher concentration of metabolites, the greater the cytotoxicity. In silico analyzes demonstrate that some of these compounds have a better interaction with the protease nsP2 CHIKV and MAYV, which suggests a model of mechanism.

An extract to be considered with potential antiviral activity will have a reduction

323 of between 50 and $90 \%$ in the number of plaques when compared to controls. On the other hand, to be considered antiviral, the extract will need a $>90 \%$ reduction [38]. The methanolic extract obtained by soxhlet, $\mathrm{CAH} 24$, when compared with the maceration method, CAH21, showed higher antiviral potential activity against CHIKV and MAYV.

327 The soxhlet system temperature remains high during the extraction process, higher 
328 solubility and diffusivity of the sample is achieved [39]. Therefore, the use of high 329 temperature provided a higher extraction of biologically active antiviral metabolites in $C$.

$330 a l b a$, although it also showed a more cytotoxic profile. HPLC analysis of C. alba extracts 331 showed $28(\mathrm{CAH} 21)$ and 21 (CAH24) peaks (See S2 and S3 Figs.). However, since we 332 used only 16 known standards molecules (See S1 Fig), it was possible to identify only 6 333 metabolites: naringin, syringic acid, chlorogenic acid, vitexin, myricetin, and quercetin. 334 The use of different extraction methods and preparation of $C$. alba extracts, aimed to 335 evaluate and compare the profiles obtained in cytotoxicity and antiviral tests, as well as 336 in chromatographic analysis, identifying some different metabolites. against arboviruses. Since we do not know which compound or compounds are 339 responsible for the possible antiviral activity of both extracts, it would be necessary to 340 fractionate the different compounds present in the extract to test their antiviral activity.

341 According to our results, we hypothesize that flavonoids found in C. alba could be able 342 to interact with viral replication enzymes, which are described in the literature as having 343 antiviral activity [14, 40, 41], mainly against arboviruses [42-47], and against influenza 344 viruses [48], enteroviruses [49, 50], and hepatitis viruses [51, 52]. Antiviral activity of 345 four flavonoids (quercetin, naringin, hesperetin, and daidzein) was analyzed against 346 dengue virus-type 2 (DENV-2) through plaque assay. When it was used after virus 347 adsorption, quercetin showed an $\mathrm{IC}_{50}$ of $35.7 \mu \mathrm{g} / \mathrm{mL}$. Naringin showed an $\mathrm{IC}_{50}=168,2$ $348 \mu \mathrm{g} / \mathrm{mL}$ before virus adsorption. Daidzein exhibited low activity anti-DENV-2 and 349 hesperetin was not antiviral against DENV-2. Besides, the DENV-2 RNA production 350 level decreased in the presence of $50 \mu \mathrm{g} / \mathrm{mL}$ of quercetin, achieving a $67 \%$ viral reduction 
when compared to the control [46]. The quercetin and the naringenin flavonoids showed antiviral activity against MAYV and DENV-1 to 4, respectively $[50,51]$.

flavonoids canferol, quercetin (founds in M. charantia), and luteolin were responsible for the antiviral action [53]. Among the aforementioned flavonoids, two were identified in identified in CAH24, until the present study, has not been correlated with arboviruses' antiviral activities, and there are few studies on chlorogenic acid antiviral activity [54].

361 However, the authors [55] suggested that the antiviral activity (anti-Herpes Simples

Virus, HSV) of substances isolated from Persea americana species may be due to a synergism between flavonoids and chlorogenic acid. proteins. The separation of nonpolar and polar components from plant extracts may

369 increase the chance of finding highly active antiviral compounds with low cytotoxicity

370 [56]. Therefore, elucidating the antiviral mechanism of $C$. alba extracts requires the

371 identification of their biologically active constituents, allowing the active principle to be 372 used without the interference of other metabolites. The possible antiviral activity found 373 in the C. alba extracts can be attributed to the presence of major components, such as 374 flavonoids and/or minor components, unidentified, present in the extract. 

identified in the $C$. alba extracts with the protease nsP2 of CHIKV and MAYV was

377 carried out. Although we have not identified all metabolites of the two methanolic C. alba 378 extracts, the molecules that have been detected were used for in silico interactions 379 analysis against the CHIKV and MAYV nsP2 proteins. Besides protease activity, nsP2 380 presents other enzymatic activities during viral replication, such as RNA helicase and RNA triphosphatase - that are responsible for unwinding the duplex RNA and removing the phosphate-5 'group from viral RNA during the capping reaction [57]. Molecular interactions analysis by molecular docking, in the active sites of nsP2, for both CHIKV and MAYV, showed that the most common chemical bond found was the van der Waals type. Although the van der Waals type molecular interactions are considered weak, other interactions may happen due to a good correlation between the protein binding site and the ligand structure [58].

CHIKV nsP2 has a high-resolution crystal structure available which facilitates the search for antiviral molecules [59]. To build the MAYV nsP2 crystal structure, the Ramachandran graph is one of the best quality analyses to select experimental structure models. The values report the distribution of the protein torsion angles $(\varphi, \Psi)$. The

392 reference parameter should be close to $96 \%$ [60]. Recently, a flavanone glycoside393 naringin that binds to $\mathrm{nsP} 2$ protease at $\mathrm{nM}$ affinity was identified, via a combination of receptor-based docking and Molecular Dynamics (MD) simulations [61]. The authors submitted the protease-naringin complex to MD simulations, whose objective was to test the stability of the protein-ligand complex. According to the ParDOCK server used, 397 naringin presented a strong connection with the nsP2 active site, which was validated in 398 biomolecular interaction studies, with affinity energy equal to $-9.47 \mathrm{kcal} / \mathrm{mol}$, 
399 corroborating our results. An in silico study of possible molecular interactions between

$400 \mathrm{CHIKV}$ nsP3 and three flavonoids potential ligands was conducted. Among of the

401 compounds, the flavonoid baicalin obtained the best affinity binding $(-9.8 \mathrm{kcal} / \mathrm{mol})$,

402 showing be like potential inhibitor of CHIKV nsP3 [58].

403 Until the present study and to our knowledge, this is the first work that shows the

404 interaction between flavonoids and MAYV nsP2 protease in silico. However, the antiviral

405 activity of the flavonoid epicatechin isolated from Salacia crassifolia against the MAYV

406 capsid protein (protein C) was identified [27]. The activity anti-MAYV and anti-CHIKV

407 of silymarin flavonoid was also confirmed by in vitro biologic assays [62, 63]. Plants'

408 use in Brazilian traditional medicine for the treatment of various diseases is increasing

409 due to the diversity of bioactive constituents present in them, being potential sources of

410 antiviral substances [12, 42]. In this context, the prospection of new drugs of plant origin

411 remains relevant, considering the number of publications demonstrating the antiviral

412 activity of plant derivatives [10], combined with the wide structural diversity found in

413 these substances, in addition to the wide availability in nature [11]. 


\section{Conclusion}

417 anti-MAYV. In silico analysis the flavonoids naringin and vitexin showed high ligand

418 affinity to the protease enzyme nsP2 from CHIKV and MAYV, we therefore,

419 hypothesized that these bioligands may inhibit viral replication. As many natural

420 products, $C$. alba roots are a potential source of antiviral compounds for the development

421 of antiviral drugs against viral infections that affect millions of people worldwide. 


\section{Acknowledgments}

423 This work was supported by grants from the National Council of Scientifc and

424 Technological Development (CNPq - process numbers: 313455/2019-8; 427304/2018-0;

$425308576 / 2018-7$ ), Tocantins State Foundation for Research Aid (FAPT-SESAU/TO-

426 DECIT/SCTIE/MS_CNPQ/N 01/2017) and Federal University of Tocantins (PROPESQ) -

427 EDITAL N 29/2020 PROPESQ and PPGBIOTEC/UFT/GURUPI- Chamada pública para

428 auxílio de tradução e/ou publicação de artigos científicos - EDITAL No 011/2020.

429

430 Conflict of interest

431 The authors declare that they have no conflict of interest.

432 


\section{References}

434 [1] Cleton N, Koopmans M, Reimerink J, Godeke GJ, Reusken C. Come fly with me: 435 review of clinically important arboviruses for global travelers. Journal of Clinical 436 Virology. 2012; 55, 191-203. doi: 10.1016/j.jcv.2012.07.004

[2] Pereira TN, Carvalho FD, De Mendonça SF, Rocha MN, Moreira LA. Vector competence of Aedes aegypti, Aedes albopictus, and Culex quinquefasciatus mosquitoes for Mayaro virus. PLoS Negl Trop Dis. 2020; 14, e0007518. doi: 10.1371/journal.pntd.0007518

443 [3] Contigiani MS, Diaz LA. Togaviridae. In Arthropod borne diseases. Springer Cham. 2017; 115-135. doi:10.1007/978-3-319-13884-8_9

[4] Pego PN, Gomes LP, Provance-Jr DW, De-Simone SG. Mayaro Virus Disease. 447 Journal of Human Virology \& Retrovirology. 2014; 1, 00018. 448 Doi:10.15406/jhvrv.2014.01.00018

[5] Kielian M, Chanel-Vos C, Liao M. Alphavirus Entry and Membrane Fusion. Viruses. 2010; 2, 796-825. doi: 10.3390/v2040796 alphavirus protein interactomes from a therapeutic perspective. Antiviral research. 2019; 163, 125-139. doi: 10.1016/j.antiviral.2019.01.015

[7] Nguyen PT, Yu H, Keller PA. Identification of Chikungunya virus nsP2 protease inhibitors using structure-base approaches. Journal of Molecular Graphics and Modelling. 2015; 57, 1-8. doi: 10.1016/j.jmgm.2015.01.001 opportunities for medicinal chemistry. Journal of Medicinal Chemistry. 2014; 57, 11471166. doi: 10.1021/jm400460d

[10] Lin LT, Hsu WC, Lin CC. Antiviral natural products and herbal medicines. Journal of traditional and complementary medicine. 2014;4, 24-35. doi: 10.4103/2225-

472 [11] Sharma P, Manchanda R, Goswami R, Chawla S. Biodiversity and therapeutic 473 potential of medicinal plants. In Environmental Concerns and Sustainable Development: 
474 Volume 2: Biodiversity, Soil and Waste Management, Springer, Singapore. 2020; 27-44.

475 doi: 10.1007/978-981-13-6358-0 2

476

477

[12] Akram M, Tahir IM, Shah SMA, Mahmood Z, Altaf A, Ahmad K, et al. Antiviral

478

479 potential of medicinal plants against HIV, HSV, influenza, hepatitis, and coxsackievirus: a systematic review. Phytotherapy Research. 2018; 32, 811-822. doi: 10.1002/ptr.6024

[13] Zaynab M, Fatima M, Abbas S, Sharif Y, Umair M, Zafar MH, Bahadar K. Role of secondary metabolites in plant defense against pathogens. Microbial pathogenesis. 2018; 124, 198-202. https://doi.org/10.1016/j.micpath.2018.08.034

[14] Zakaryan H, Arabyan E, Oo A, Zandi K. Flavonoids: promising natural compounds against viral infections. Archives of virology. 2017; 162, 2539-2551. doi: 10.1007/s00705-017-3417-y

[15] Aro AO, Dzoyem JP, Goddard A, Fonteh P, Kayoka-Kabongo PN, McGaw LJ. In vitro Antimycobacterial, Apoptosis-Inducing Potential, and Immunomodulatory Activity of Some Rubiaceae Species. Front Pharmacol. 2019 Mar 5;10:185. doi: 10.3389/fphar.2019.00185.

[16] Rivero-Cruz I, Cristians S, Ovalle-Magallanes B, Mata R. Mexican copalchis of the 495 Rubiaceae family: more than a century of pharmacological and chemical investigations. Phytochemistry Reviews. 2019; 18, 1435-1455. doi: 10.1007/s11101019-09618-y

[17] Martins D, Nunez CV. Secondary metabolites from Rubiaceae species. Molecules.

[18] Gazda VE, Gomes-Carneiro MR, Barbi NS, Paumgartten FJ. Toxicological evaluation of an ethanolic extract from Chiococca alba roots. Journal of ethnopharmacology. 2006; 105, 187-195. doi: 10.1016/j.jep.2005.10.017

[19] Bhattacharyya J, Cunha EV. A triterpenoid from the root-bark of Chiococca

[20] Comerford SC. Medicinal plants of two mayan healers from San Andrés, Petén, 510 Guatemala. Economic Botany. 1996; 50, 327-336

512 [21] Rico-Gray V, Chemás A, Mandujano S. Uses of tropical deciduous forest species by 513 the Yucatecan Maya. Agroforestry systems. 1991; 14, 149-161. doi: $514 \quad 10.1007 / B F 00045730$ 
516 [22] Hernández-Bolio GI, Ruiz-Vargas JA, Peña-Rodríguez LM. Natural Products from 517 the Yucatecan Flora: Structural Diversity and Biological Activity. J Nat Prod. 2019 Mar 518 22; 82(3): 647-656. doi: 10.1021/acs.jnatprod.8b00959

[23] Borges RM, Valença SS, Lopes AA, dos Santos Barbi N, da Silva AJR. Saponins from the roots of Chiococca alba and their in vitro anti-inflammatory activity. Phytochemistry Letters. 2013; 6, 96-100

[24] Aguiar RW, dos Santos SF, da Silva Morgado F, Ascencio SD, de Mendonça Lopes M, Viana KF, Didonet J, Ribeiro BM. Insecticidal and repellent activity of Siparuna guianensis Aubl. (Negramina) against Aedes aegypti and Culex quinquefasciatus. PLoS One. 2015 Feb 3;10(2):e0116765. doi: 10.1371/journal.pone.0116765

527 [25] Sriphana U, Yenjai C, Tungnoi S, Srirapa J, Junsongduang A. Flavonoids from 528 Milletia leucantha and Their Cytotoxicity. Natural Product Communications. 2018; 13. 961-962. doi: 10.1177/1934578X1801300810

[26] Chen SG, Leu YL, Cheng ML, Ting SC, Liu CC, Wang SD, et al. Anti-enterovirus 71 activities of Melissa officinalis extract and its biologically active constituent rosmarinic acid. Scientific reports. 2017; 7, 1-16. doi :10.1038/s41598-017-12388-2

[27] Ferreira PG, Ferraz AC, Figueiredo JE, Lima CF, Rodrigues VG, Taranto AG, et al. Detection of the antiviral activity of epicatechin isolated from Salacia crassifolia (Celastraceae) against Mayaro virus based on protein C homology modelling and virtual screening. Archives of virology. 2018; 163, 1567-1576. doi: 10.1007/s00705-018-37741

542

543

[28] Burleson FG, Chambers TM, Wiedbrauk DL. 1992. Técnicas para avaliar agentes

544

545 [29] Troian EA, Schallenberger K, da Silva FP, Dietrich GK, Ferreira Chiesa F, Olivaro 546 C, et al. Screening for antiviral activity of two purified saponin fractions of Quillaja spp. 547 against Yellow fever virus and Chikungunya virus. International Journal for Innovation 548 Education and Research. 2020; 8, 205-214. doi: 10.31686/ijier.vol8.iss9.2615

[30] Parone PA, Da Cruz S, Cleveland DW. Mitochondrial isolation and purification from 552

553 [31] Repetto G, Del Peso A, Zurita JL. Neutral red uptake assay for the estimation of cell 554 viability/cytotoxicity. Nature protocols. 2008; 3, 1125. doi: 10.1038/nprot.2008.75 
557 Cytotoxicity and antiviral activity evaluation of Cymbopogon spp hydroethanolic

558 extracts. Brazilian Journal of Pharmaceutical Sciences. 2019; 55. doi: 10.1590/s2175-

55997902019000118063

[33] Sanner MF. Python: a programming language for software integration and development. J Mol Graph Model. 1999 Feb;17(1):57-61

[34] Moura W, de Souza SR, Campos FS, Cangussu ASR, Santos EMS, Andrade BS, et al. Antibacterial activity of Siparuna guianensis essential oil mediated by impairment of membrane permeability and replication of pathogenic bacteria. Industrial Crops and Products. 2020; 146, 112-142. doi: 10.1016/j.indcrop.2020.112142

[35] Trott O, Olson AJ. AutoDock Vina: improving the speed and accuracy of docking with a new scoring function, efficient optimization, and multithreading. Journal of computational chemistry. 2010; 31, 455-461. doi: 10.1002/jcc. 21334

[36] Schrodinger LLC. The PyMOL molecular graphics system, vo.2.2.2 (Version 2.2.2).

[37] Dassault Systems BIOVIA. Discovery Studio Modeling Environment, Release 2017. Dassault Systems, San Diego.

[38] Hobohm U, Sander C. A sequence property approach to searching protein databases. Journal of molecular biology. 1995;251, 390-399. doi: 10.1006/jmbi.1995.0442

[39] Zou J, Yin J, Fang L, Yang M, Wang T, Wu W, et al. Computational Prediction of Mutational Effects on SARS-CoV-2 Binding by Relative Free Energy Calculations. Journal of chemical information and modeling. 2020; 60, 5794-5802. doi: 10.1021/acs.jcim.0c00679 al. Antiviral Activity and Mode of Action of Propolis Extracts and Selected Compounds. Phytotherapy Research. 2009; 24, S20-S28. doi: 10.1002/ptr.2868

[41] De Castro ML, García-Ayuso LE. Soxhlet extraction of solid materials: an outdated technique with a promising innovative future. Analytica chimica acta. 1998; 369, 1-10. doi: 10.1016/S0003-2670(98)00233-5

[42] Ninfali P, Antonelli A, Magnani M, Scarpa ES. Antiviral properties of flavonoids and delivery strategies. Nutrients. 2020; 12, 2534. doi: 10.3390/nu12092534 
598

599

600

601

602

603

604

605

606

607

608

609

610

611

612

613

614

615

616

617

618

619

620

621

622

623

624

625

626

627

628

629

630

631

632

633

634

635

636

637

638

639

640

[43] Solnier J, Fladerer JP. Flavonoids: A complementary approach to conventional therapy of COVID-19? Phytochem Rev. 2020 Sep 18:1-23. doi: 10.1007/s11101-02009720-6

[44] Goh VSL, Mok CK, Chu JJH. Antiviral natural products for arbovirus infections. Molecules. 2020; 25, 2796. doi: 10.3390/molecules25122796

[45] Jayadevappa MK, Karkera PR, Siddappa RY, Telkar S, Karunakara P. Investigation of plant flavonoids as potential dengue protease inhibitors. Journal of Herbmed Pharmacology. 2020; 9, 366-373. doi: 10.34172/jhp.2020.46

[46] Oliveira AFCDS, Teixeira RR, Oliveira ASD, Souza APMD, Silva MLD, Paula SOD. Potential antivirals: Natural products targeting replication enzymes of dengue and chikungunya viruses. Molecules. 2017; 22, 505. doi: 10.3390/molecules22030505

[47] Ahmadi A, Hassandarvish P, Lani R, Yadollahi P, Jokar A, Bakar SA, et al. Inhibition of Chikungunya virus replication by hesperetin and naringenin. RSC advances. 2016; 6, 69421-69430. doi: 10.1039/C6RA16640G

[48] Zandi K, Teoh BT, Sam SS, Wong PF, Mustafa MR, Abu Bakar S. Antiviral activity of four types of bioflavonoid against dengue virus type-2. Virology journal. 2011; 8, 111. doi: $10.1186 / 1743-422 X-8-560$

[49] Sanchéz I, Gómez-Garibay F, Taboada J, Ruiz BH. Antiviral effect of flavonoids on the dengue virus. Phytotherapy Research: An International Journal Devoted to Pharmacological and Toxicological Evaluation of Natural Product Derivatives. 2000; 14 , 89-92. doi: 10.1002/(SICI)1099-1573(200003)14:2<89::AID-PTR569>3.0.CO;2-C

[50] Grienke U, Richter M, Walther E, Hoffmann A, Kirchmair J, Makarov V, Nietzsche S, Schmidtke M, Rollinger JM. Discovery of prenylated flavonoids with dual activity against influenza virus and Streptococcus pneumoniae. Sci Rep. 2016 Jun 3;6:27156. doi: $10.1038 /$ srep 27156

[51] Lalani S, Poh CL. Flavonoids as antivirals agents for Enterovirus A71 (EVA71). Viruses. 2020; 12, 184. doi: 10.3390/v12020184

[52] Shimizu JF, Lima CS, Pereira CM, Bittar C, Batista MN, Nazaré AC. Flavonoids from Pterogyne nitens inhibit hepatitis C virus entry. Scientific reports. 2017; 7, 1-9. doi: 10.1038/s41598-017-16336-y

[53] Calland N, Albecka A, Belouzard S, Wychowski C, Duverlie G, Descamps V, et al. (-)-Epigallocatechin-3-gallate is a new inhibitor of hepatitis $C$ virus entry. Hepatology. 2012; 55, 720-729. doi: 10.1002/hep.24803 
641 [54] Frabasile S, Koishi AC, Kuczera D, Silveira GF, Verri WA, Dos Santos CND, et al.

642 The citrus flavanone naringenin impairs dengue virus replication in human

643 cells. Scientific reports. 2017; 7, 1-11. doi: 10.1038/srep41864

644

645 [55] dos Santos AE, Kuster RM, Yamamoto KA, Salles TS, Campos R, de Meneses MD, 646 et al. Quercetin and quercetin 3-O-glycosides from Bauhinia longifolia (Bong.) Steud. 647 show anti-Mayaro virus activity. Parasites \& vectors. 2014; 7, 1-7. doi: 10.1186/1756$648 \quad 3305-7-130$

649

[56] Tang LI, Ling AP, Koh RY, Chye SM, Voon KG. Screening of anti-dengue activity in methanolic extracts of medicinal plants. BMC complementary and alternative medicine. 2012; 12, 3. doi: 10.1186/1472-6882-12-3

[57] Miao M, Xiang L. Pharmacological action and potential targets of chlorogenic acid. Advances in Pharmacology. 2020; 87, 71-88. doi: 10.1016/bs.apha.2019.12.002 compounds from immature avocado fruit peel. Phytochemistry. 1992; 31, 93-96. doi: 10.1016/0031-9422(91)83013-B antiviral and cytotoxic activities of methanolic extract of $S$. grandiflora (Fabaceae) flowers. Asian Pacific Journal of Tropical Biomedicine. 2012; 2, S855-S858. doi: 10.1016/S2221-1691: 60323-2

[60] Bissoyi A, Pattanayak SK, Bit A, Patel A, Singh AK, Behera SS, Satpathy D. Alphavirus nonstructural proteases and their inhibitors. In Viral proteases and their inhibitors. Academic Press. 2017; 77-104. doi: 10.1016/B978-0-12-809712-0.00004-6

[61] Seyedi SS, Shukri M, Hassandarvish P, Oo A, Shankar EM, Abubakar S, Zandi K. Computational approach towards exploring potential anti-chikungunya activity of 673 selected flavonoids. Scientific reports. 2016; 6, 1-8. https://doi.org/10.1038/srep24027

679 [63] Sobolev OV, Afonine PV, Moriarty NW, Hekkelman ML, Joosten RP, Perrakis A, 680 Adams PD. A Global Ramachandran Score Identifies Protein Structures with Unlikely 681 Stereochemistry. Structure. 2020 Nov 3;28(11):1249-1258.e2. doi: of Chikungunya virus nsP2 cysteine protease reveals a putative flexible loop blocking its active site. International journal of biological macromolecules. 2018; 116, 451-462. doi: 10.1016/j.ijbiomac.2018.05.007

683 
684 [64] Tripathi PK, Singh J, Gaurav N, Garg DK, Patel AK. In-silico and biophysical 685 investigation of biomolecular interaction between naringin and nsP2 of the Chikungunya 686 virus. International Journal of Biological Macromolecules. 2020; 160, 1061-1065. doi: 687 10.1016/j.ijbiomac. 2020.05.165

688

689 [65] Camini FC, da Silva TF, da Silva Caetano CC, Almeida LT, Ferraz AC, Vitoreti 690 VMA, et al. Antiviral activity of silymarin against Mayaro virus and protective effect in 691 virus-induced oxidative stress. Antiviral research. 2018;158, 8-12. doi: 692 10.1016/j.antiviral.2018.07.023

693

694 [66] Lani R, Hassandarvish P, Chiam CW, Moghaddam E, Chu JJH, Rausalu K, et al. 695 Antiviral activity of silymarin against chikungunya virus. Scientific reports. 2015; 5, 1696 10. doi: 10.1038/srep11421 


\section{Supporting information}

703 S1 Fig. Authentic standards fingerprint available in High-Performance Liquid

704 Chromatography (HPLC). Source: Laboratory of Scientific Instrumentation (LABIC),

705 Federal University of Tocantins.

706

707 S2 Fig. The fingerprint obtained by HPLC of the methanolic extract obtained from

708

C. alba roots (CAH21). Peak 09: Naringin, detected at $280 \mathrm{~nm}$. The separation was

709

performed on a C18 Phenomenex Luna column and gradient system, with mobile phase

710 A $0.1 \%$ phosphoric acid in Milli-Q water and mobile phase B $0.1 \%$ phosphoric acid in

711 Milli-Q / acetonitrile-water / methanol in the ratio 54:35:11 (v / v).

712

713 S3 Fig. The fingerprint obtained by HPLC of the methanolic extract obtained from

714 C. alba roots (CAH24). Peak 05: syringic acid, 06: chlorogenic acid, 10: vitexin, 12:

715 myricetin, and 14: quercetin, detected at $280 \mathrm{~nm}$. The separation was performed in a C18

716 Phenomenex Luna column and gradient system, with mobile phase A $0.1 \%$ of phosphoric

717 acid in water Milli-Q and mobile phase B, 0.1\% phosphoric acid in Milli-Q / acetonitrile-

718 water / methanol in the ratio 54:35:11 (v/v).

719

720 S4 Fig. Plaque assay for CAH21 and CAH24 C. alba extracts against CHIKV on

721 Vero cells monolayer for 48 hours. $\mathrm{CC}=$ cellular control; $\mathrm{VC}=$ viral control; $\mathrm{CC}$

$722 \mathrm{CAH} 21=$ cytotoxic control with $100 \mu \mathrm{g} / \mathrm{mL}$ of $\mathrm{CAH} 21$, and $\mathrm{CC}$ CAH24= cytotoxic

723 control with $100 \mu \mathrm{g} / \mathrm{mL}$ of CAH24. Concentrations: $100=100 \mu \mathrm{g} / \mathrm{mL} ; 80=80 \mu \mathrm{g} / \mathrm{mL}$;

$72460=60 \mu \mathrm{g} / \mathrm{mL}$, and $40=40 \mu \mathrm{g} / \mathrm{mL}$.

725 
bioRxiv preprint doi: https://doi.org/10.1101/2021.08.04.455105; this version posted August 4, 2021. The copyright holder for this preprint (which was not certified by peer review) is the author/funder, who has granted bioRxiv a license to display the preprint in perpetuity. It is made available under aCC-BY 4.0 International license.

726 S5 Fig. Plaque assay for CAH21 (A) and CAH24 (B) C. alba extracts against MAYV

727 on Vero cells monolayer for 48 hours. $\mathrm{CC}=$ cellular control; $\mathrm{VC}=$ viral control; $\mathrm{CC}$

$728 \mathrm{CAH} 21=$ cytotoxic control with $100 \mu \mathrm{g} / \mathrm{mL}$ of $\mathrm{CAH} 21$, and $\mathrm{CC}$ CAH24= cytotoxic

729 control with $100 \mu \mathrm{g} / \mathrm{mL}$ of CAH24. Concentrations: $100=100 \mu \mathrm{g} / \mathrm{mL} ; 80=80 \mu \mathrm{g} / \mathrm{mL}$;

$73060=60 \mu \mathrm{g} / \mathrm{mL}$, and $40=40 \mu \mathrm{g} / \mathrm{mL}$.

731 

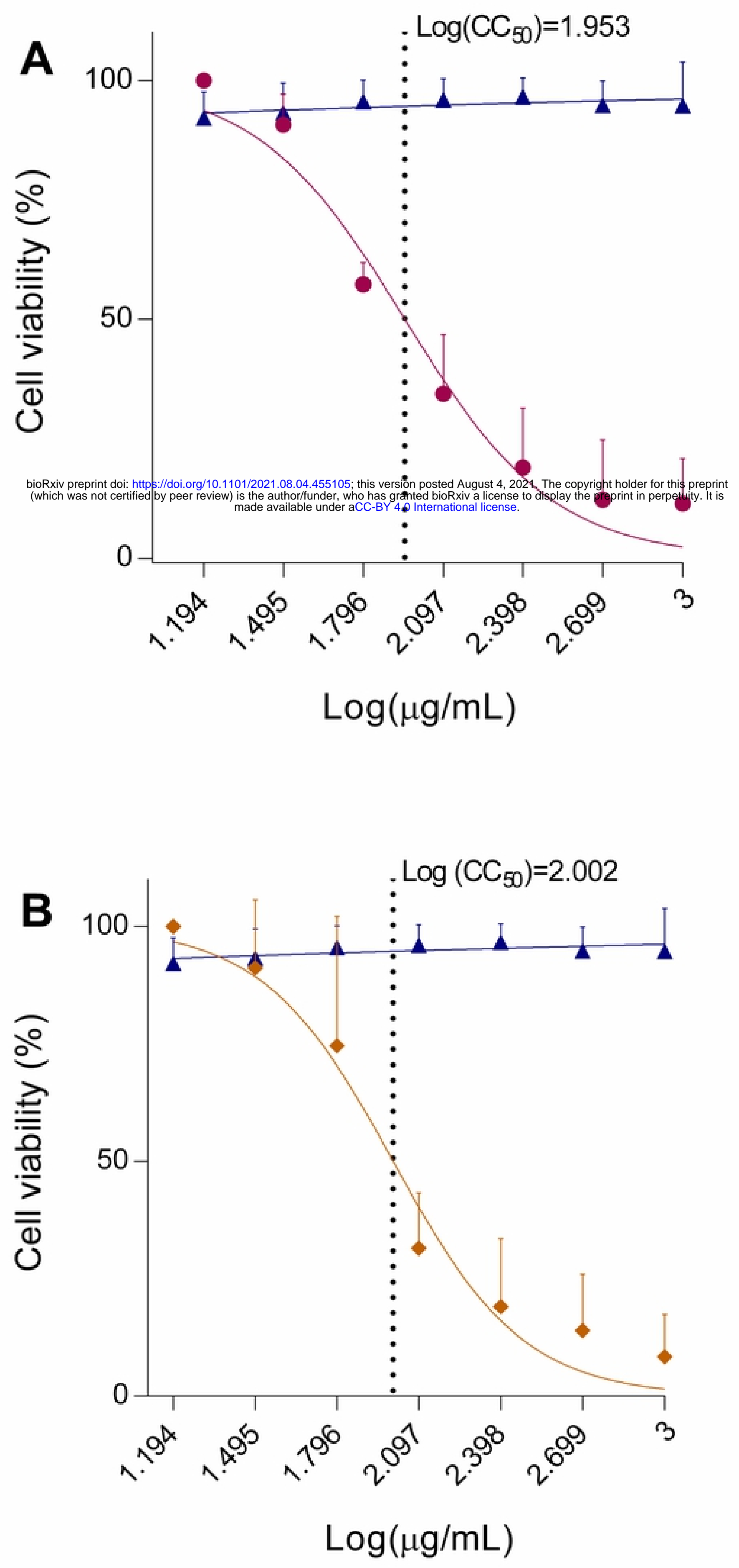

Figure 1 


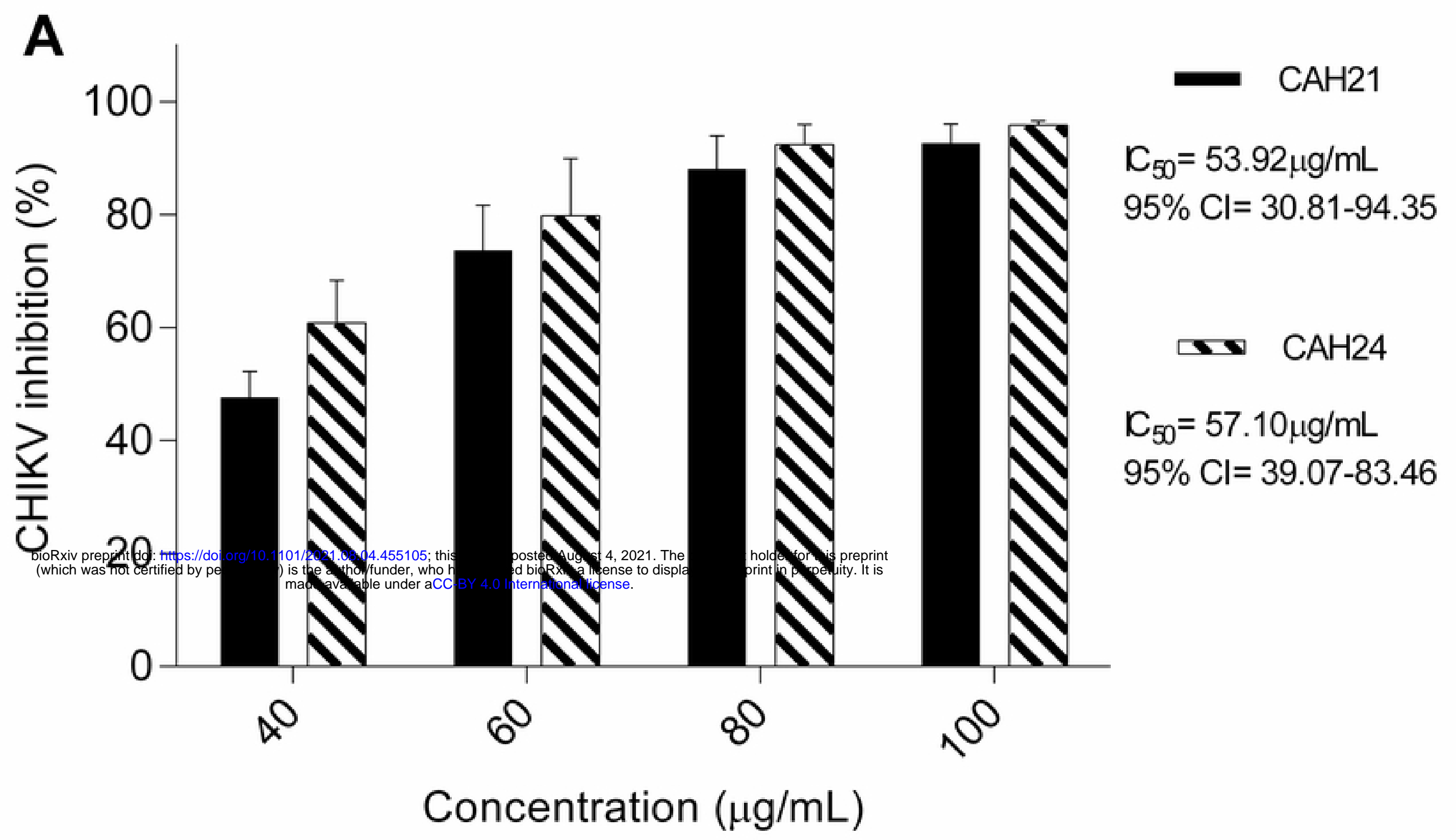

B

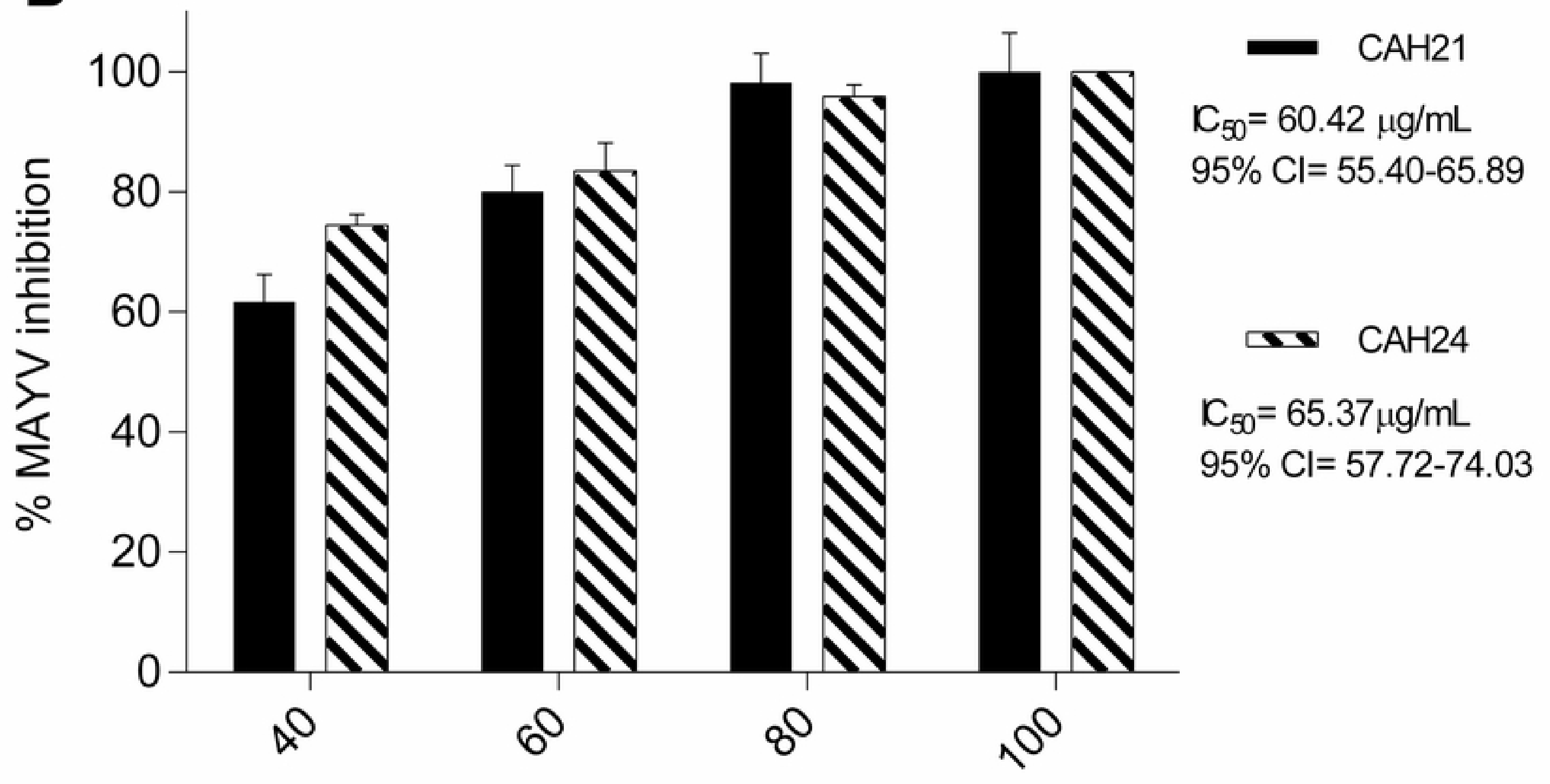

Concentration $(\mu \mathrm{g} / \mathrm{mL})$

Figure 2 


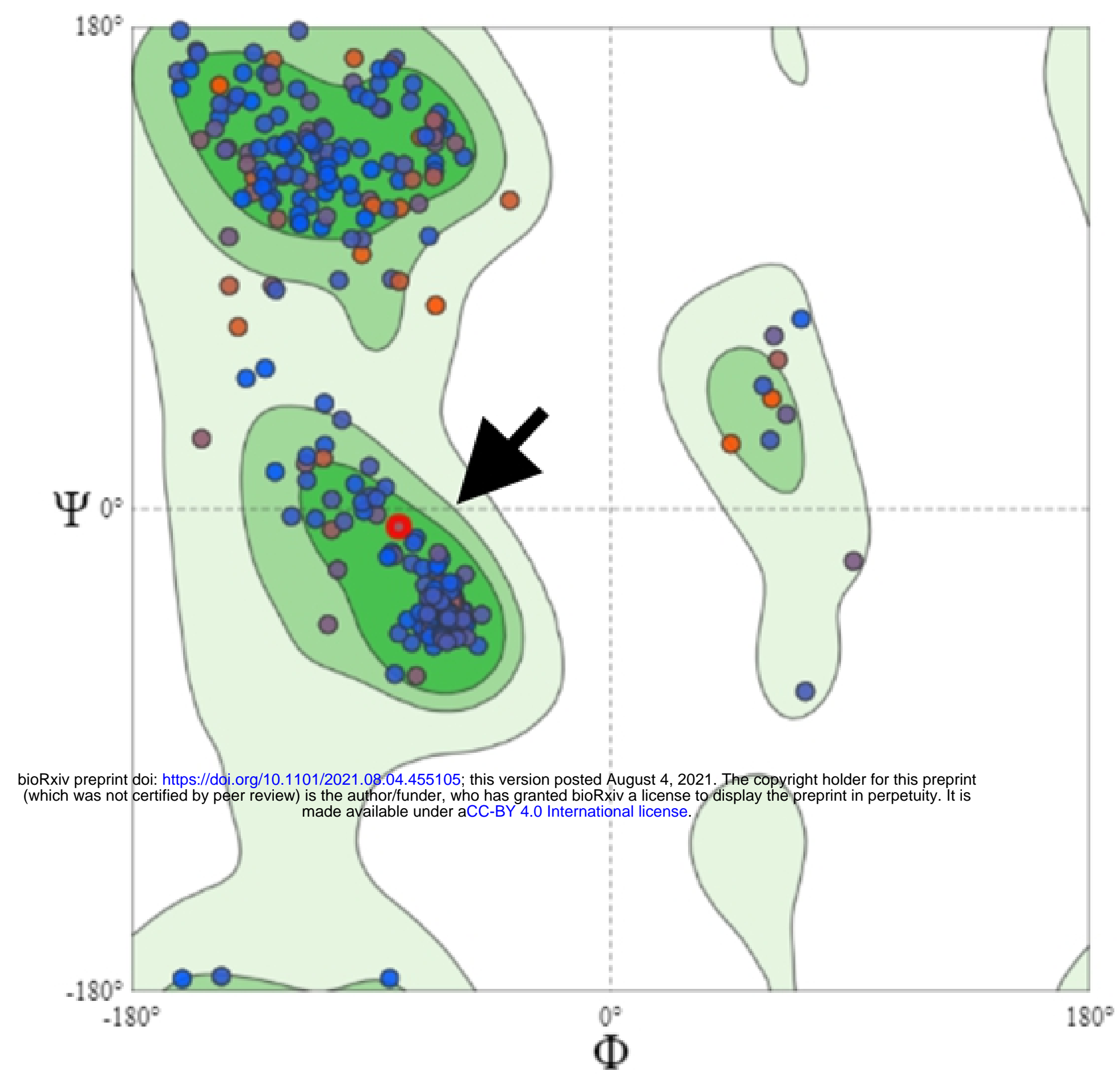

\section{Comparison with Non-redundante Set of PDB Structures} 1.5

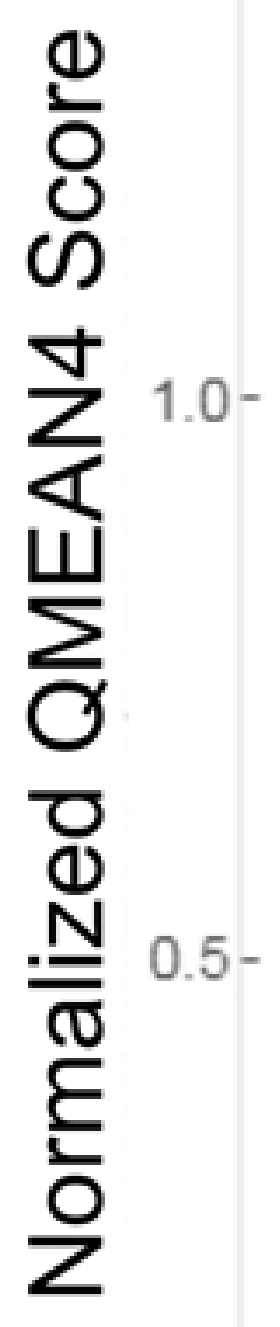

$\mid Z$-score $|>2 \bigcirc 1<| Z$-score $|<2 \bigcirc| Z$-score $\mid<1 \star$ Model

Figure 3 

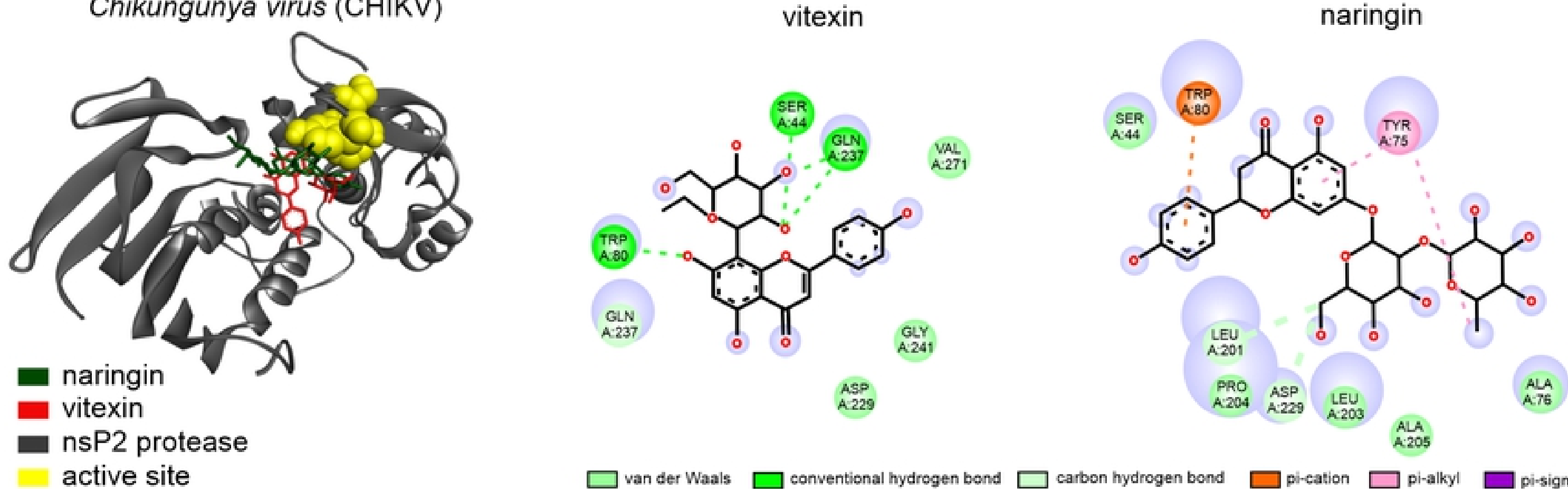
active site

$\square$ van der Waals $\square$ conventional hydrogen bond

$\square$ carbon hydrogen bond

pi-cation
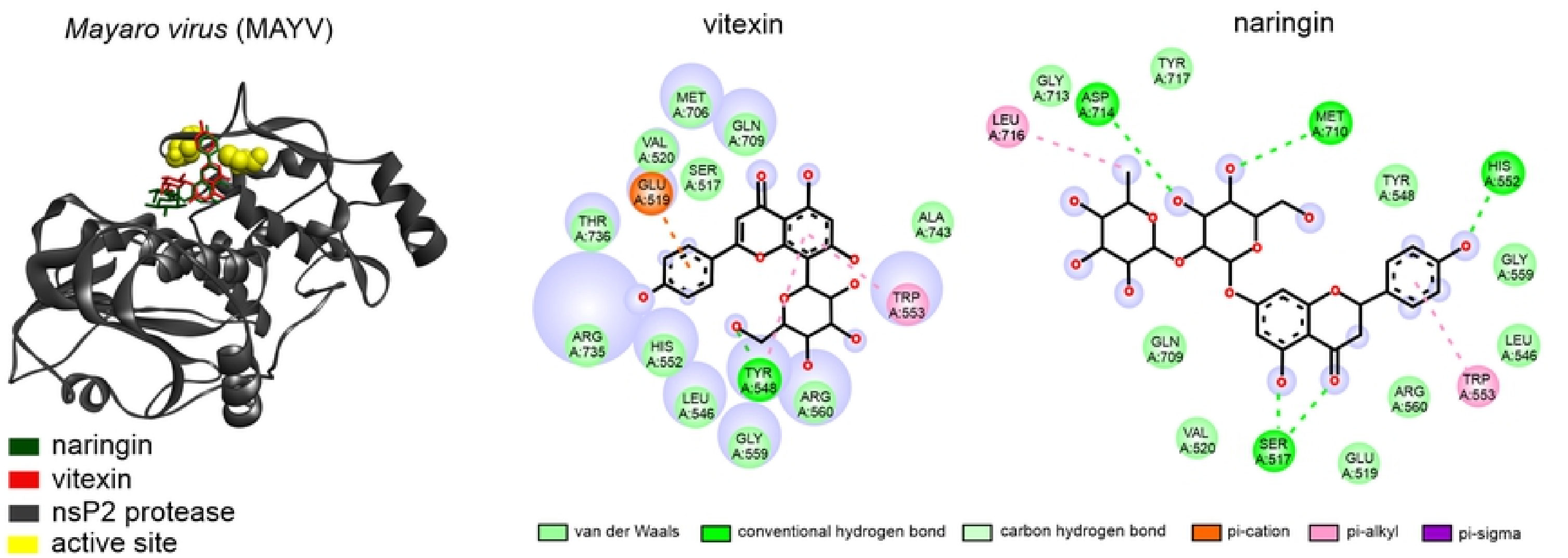

vitexin
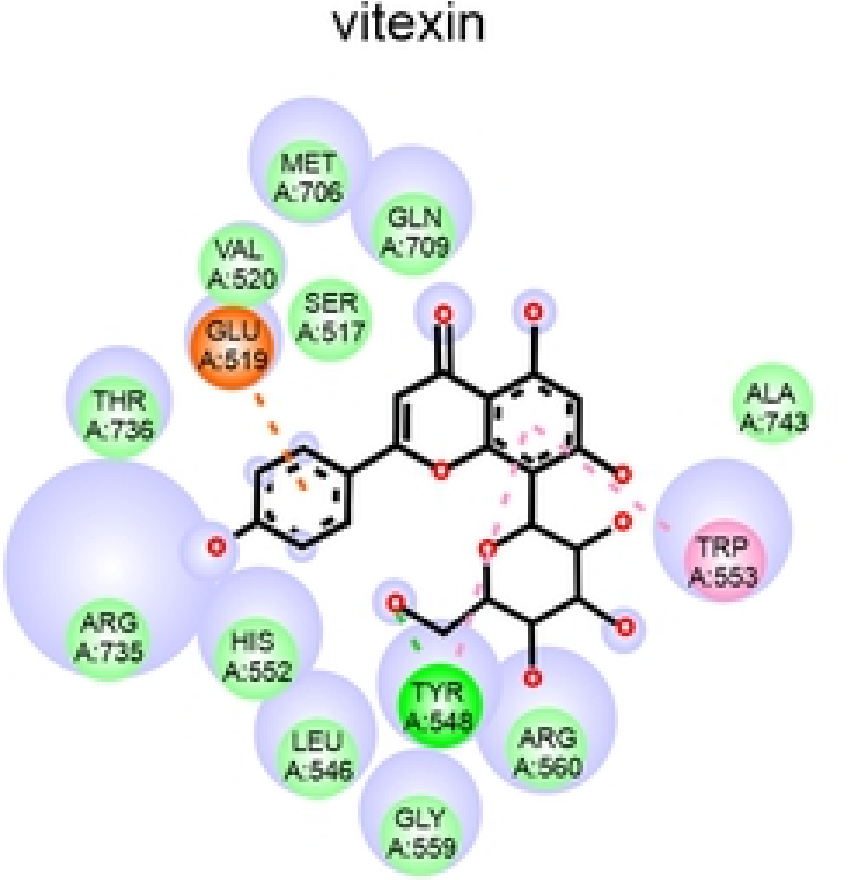

$\square$ van der Waals 